\title{
Technique of the Black Sea Temperature and Salinity Measurement Data Analysis Using Dynamic Altimetry Level
}

\author{
G.K. Korotaev, P.N. Lishaev, V.V. Knysh \\ Marine Hydrophysical Institute, Russian Academy of Sciences, Sevastopol, \\ Russian Federation \\ e-mail:gkorotaev@gmail.com, pavellish@mail.ru
}

\begin{abstract}
Original technique of combined analysis of temperature and salinity measurements and altimetry observations in the Black Sea is proposed. The technique essence consists in constructing (on the chosen horizons) the diagrams of empirical relationships between the integer sea level bins and the corresponding monthly average salinity and temperature values taken from the area bounded by the $500 \mathrm{~m}$ isobath. Such a technique permits to mark out contribution of adiabatic processes to deformation of temperature and salinity profiles. At that salinity and temperature profiles corresponding to a zero sea level bin represent an unperturbed state. The constructed in such a way (at a zero sea level) monthly average profiles of undisturbed seawater temperature and salinity are analyzed. Diagrams of seasonal and monthly average salinity profiles in $0-300 \mathrm{~m}$ layer indicates the seawater desalination in the upper $0-50 \mathrm{~m}$ layer by the end of the $1993-2002$ period. Interannual variability of monthly average temperature profiles shows decrease of cold intermediate layer thickness. Analysis of $T, S$-curves of different sea level bins reveals the fact that the profiles of temperature and salinity measured at the stations, regardless of their spatial position and time of execution, converge in $100-1200 \mathrm{~m}$ layer. This layer corresponds to intermediate water mass of the Black Sea. The given fact indicates predominant role of adiabatic processes on the selected depths.
\end{abstract}

Keywords: zero sea level bin, adiabatic processes, monthly average salinity (temperature) profile, low salinity of water, thickness of cold intermediate layer, $T, S$-curves.

DOI: 10.22449/1573-160X-2015-2-24-38

(c) 2015, G.K. Korotaev, P.N. Lishaev, V.V. Knysh

(C) 2015, Physical Oceanography

\section{Introduction}

Since October 1992 the possibility to perform the Black Sea dynamic level regular observations with a certain temporal discreteness using the data of satellite altimetry measurements [1 - 4] have appeared. It is natural to apply these observations along with data of temperature and salinity measurements for thermohaline sea structure variability analysis in a wide range of temporal scales. As it will be seen in future, it is especially important to involve the satellite altimetry for 1993 - 2013, when temperature and salinity measurements of the Black Sea were performed irregularly both by time and space.

Nowadays only a small number of works containing the analysis of such specific data is known. According to measurements of thermohaline characteristics in 1979 - 2012 V.N. Belokopytov prepared annual average temperature and salinity profiles, but their detailed analysis has not been performed yet. In the works [5 - 7] few temperature and salinity measurements performed by Argo profiling floats are considered. In [5 - 6] a procedure of so-called temperature and salinity pseudo-observations obtaining using the Argo floats measurement data for 
2007 - 2008 years and corresponding fields of dynamic altimetry sea level was developed. The formation of pseudo-observation fields is grounded in the similarity between the sea level field spatial structures and density field (salinity, temperature) in the main pynocline (constant halocline). The developed procedure allowed us (by means of optimal interpolation) to form three-dimensional monthly fields of temperature and salinity pseudo-observations on $5 \times 5$ grid and to perform their analysis. The disadvantage of this method is that the constructed temperature and salinity fields appeared to be smoothed owing to usage of autocorrelation functions, assessed according to climatic fields.

In this work [7] the spatio-temporal temperature and salinity profile variability of the Black Sea $300 \mathrm{~m}$ upper layer using the empirical orthogonal function expansion method (EOF) of Argo profiling floats data for $2002-2013$ period is studied. Warm (June - November) and cold (December - May) seasons are considered. The analysis of mode integral contribution to the total dispersion showed that to describe a spatio-temporal temperature and salinity profile variability in both data sets it is enough three EOF. In the cited work on the basis of amplitude spatial distribution analysis of considered modes an attempt of their physical interpretation is made. The assumption of the authors about horizontal anisotropy of cold intermediate layer formation (CIL) seems to be original. However, they reasonably point out that the given physical interpretation needs more independent hydrological information.

Also, we should notice the creation of specialized validation technique and software for comparing the results of thermohaline field simulation with in situ measurements, obtained by profiling floats [8].

The purpose of this work is to state a presentation of technique and results of joint temperature and salinity measurements, performed in the Black Sea in 1993 2002, and of altimetry sea level fields. The basis of the technique is the empirical dependences of average monthly salinity and temperature on depth at various bins of altimetry level. At the same time average monthly temperature and salinity profiles corresponding to "zero" level bin are identified with undisturbed condition. Performed analysis of $T$, $S$-curves allows to select the areas of adiabatic processes dominance and to characterize the long-term variability of temperature and sea water salinity fields.

\section{Construction of empirical dependences of average monthly salinity and temperature on depth at different altimetry level bins}

The construction of mentioned dependences is a basis for the suggested joint analysis technique of temperature, salinity and satellite altimetry observations of dynamic sea level contact measurement data. During the analysis the regional array of the Black Sea anomalies [1] (discreteness of time -7 days, spatial resolution $1 / 8^{\circ}$ ) and average annual climatic level [9] had been used. The fields of dynamic sea level are calculated as a sum of anomaly level and average annual climatic level values. These fields were linearly interpolated for each day of the considered period.

Topography of dynamic altimetry sea level, represented in Fig. 1, is characterized by the presence of all known structures: eastern and western cyclonic 
gyres, embracing the central part of the Black Sea, Sevastopol, Kaliakra, Bosphorus, Sakarya, Sinope, Kizilirmak, Batumi and Caucasian anticyclones located on the right of the Main Black Sea Current (MBSC). In other cases not all the selected structures are presented in the level fields. In summer period the MBSC may collapse and the number of eddy formations of different scale may increase.

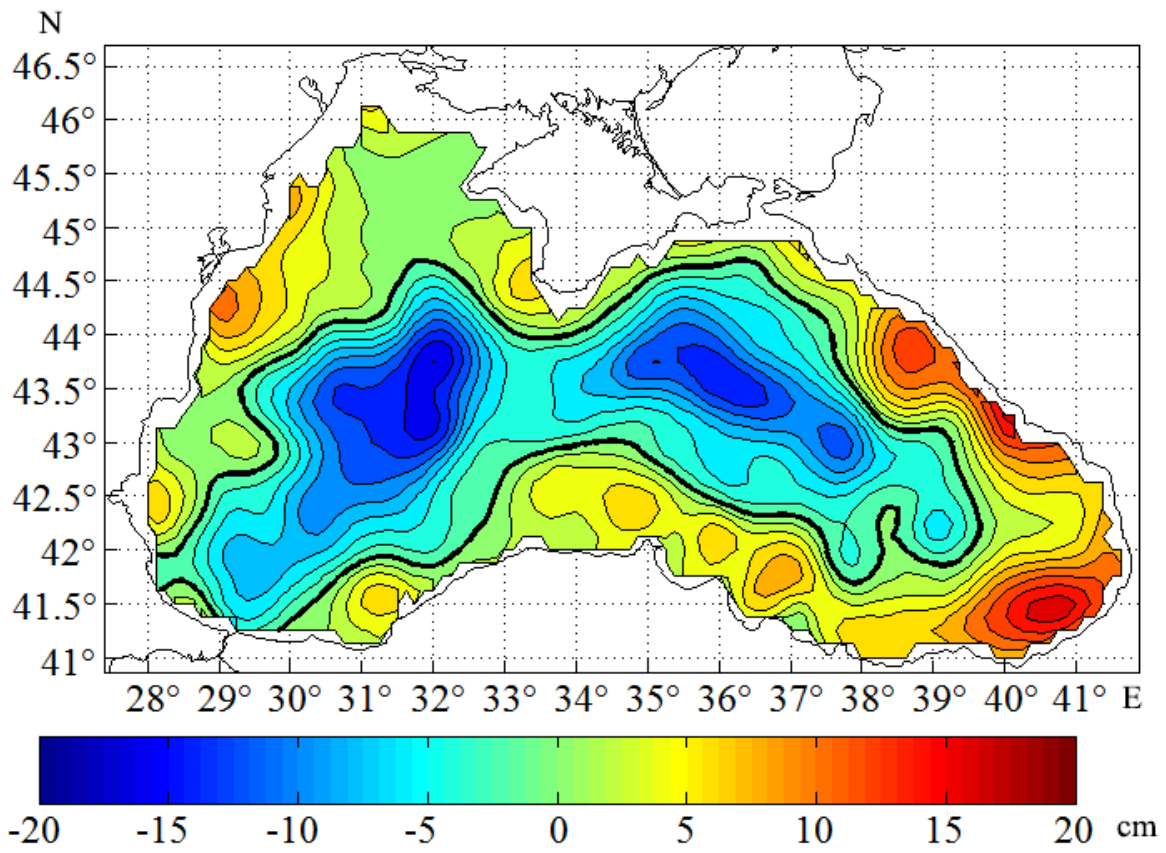

Fig. 1. Field of the Black Sea altimetry dynamic level at May 31, 1995

All sea level values were divided into bins - areas between integer isoline values of level with $1 \mathrm{~cm}$ step. For example, $\ldots, \ll-3,-2 », \ll-2,-1 », «-1,0 », \ll 0$, $1 », \ll 1,2 », \ll 2,3 », \ll 3,4 », \ldots \mathrm{cm}$. In the work there are used the arrays of the Black Sea temperature and salinity hydrological measurements for $1993-2002$, monthly composed by V. N. Belokopytov and interpolated at 2,5; 5, 10, .., 30, 40, 50, 63, 75, 88, 100, 113, 125, 150, 175, 200, 250, 300, 400, .., $2100 \mathrm{~m}$ horizons. Time (year, month, day, hours, minutes) and coordinates correspond to each vertical probing. In order to include a station, where the measurement was performed, to a certain sea level bin the interpolation of altimetry dynamic level values, corresponding to the station performing time, to the point with its coordinates was performed. For statistical provision of bins with the data of expeditionary observations it was necessary to select a quasi-optimal time interval when the measurement accumulation took place. In [5] special model numerical experiments aiming to determine such an interval were performed. They showed that it can be of $30-40$ days. In this work the authors applied a slightly extended time window, which made up 3 months (average month, which was assigned with obtained temperature and salinity value, plus (minus) one month). Such measurement accumulation time interval was conditioned by the fact that in the certain months there hadn't been enough measurements or they hadn't been performed at all (e. g. January - February - March 1997). At the same time the effect of non-adiabatic 
processes with such averaging window should not distort the laws, which are derived below.

Within each bin on the selected horizons the monthly average salinity (temperature) value had been calculated as the arithmetic mean of the corresponding parameter values at the stations, which belong to a given bin and selected time window. The monthly average value was assigned to initial bin value. Also, the values of corresponding dispersions were calculated. Besides, the measurements performed at stations in a deepwater sea area were considered. This sea area was bounded by $500 \mathrm{~m}$ isobath.

At each horizon for all period of time there were built the diagrams of empiric dependences between the values of altimetry dynamic sea level bins and corresponding monthly average salinity (temperature) values. The similar diagrams are constructed between the values of dispersions. Diagram analysis indicates the observational data provision degree of each bin at each horizon for all $1993-2002$ period.

The diagram (Fig. 2, b) shows that in March, 1993 the salinity measurement data provision at all sea level bins is ample. In October 1995 (Fig. 2, b), as in most months of that year, the measurement data don't cover the whole variability of level field. Thus, at the mentioned figure many bins are empty.
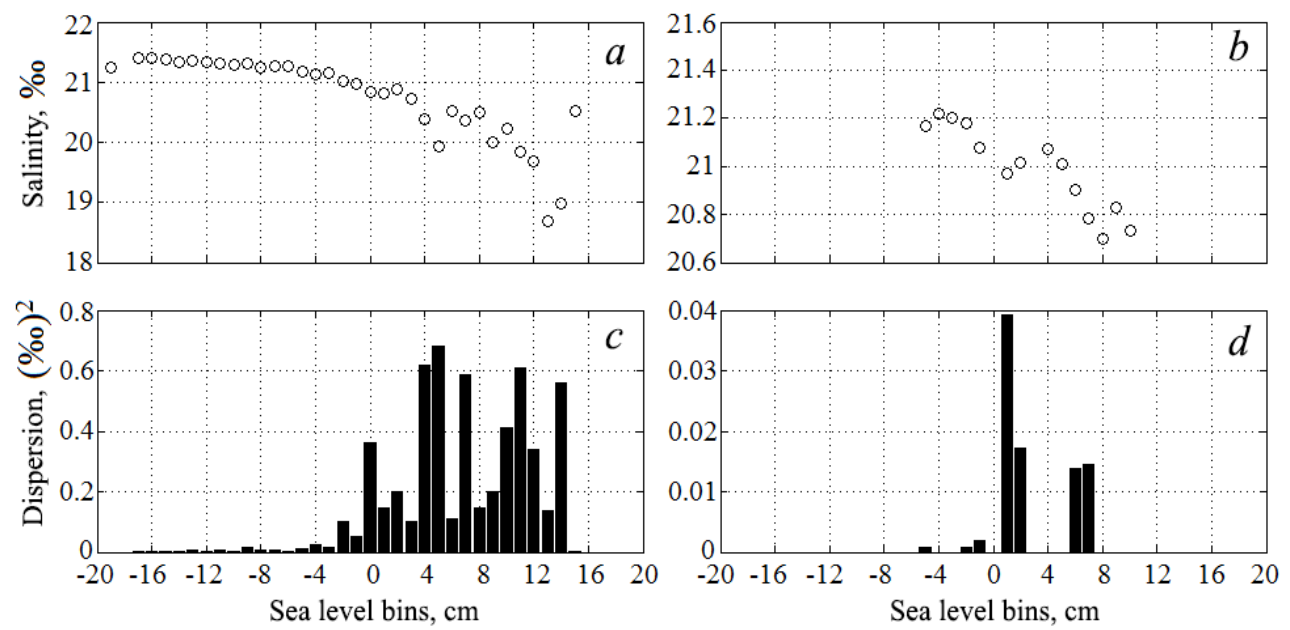

Fig. 2. Diagrams of monthly average salinity values for each sea level bin $(a, b)$ and values of corresponding dispersions (c, $d$ ) at $150 \mathrm{~m}$ horizon: $a, c$ - for March 1993; $b, d$ - for October 1995

The circulation of the Black Sea waters largely explains spatial distribution of salinity in the permanent halocline layer. Negative level bin values correspond to the western and (or) eastern cyclonic gyres and also to cyclonic eddies (if any exist). For these structures water upwelling and increased salinity values are typical. Positive values of level bins, water downwelling and decreased salinity values correspond to anticyclonic eddy formations. Fig. 2, $a, b$ also confirm the marked features of cyclonic and anticyclonic structures in those cases when there is lack of hydrological measurements data.

Monthly average temperature - altimetry level bin diagrams show more complex dependences caused by the CIL effect. An indicative one for 1993 (cold 
winter) and 1995 (normal winter) is May [10 - 14]. It was that month during which the formation of completely renewed CIL in 1993 and moderately renewed CIL in 1995, caused by spring water warming, took place [12]. Fig. 3 diagrams show that at 63 and $88 \mathrm{~m}$ horizons the monthly average temperature values, which are less than $8^{\circ} \mathrm{C}$, prevail. They characterize CIL waters in the range of all positive and negative level bins. The values of monthly average temperature in May 1995 are higher than in May 1993. The increased temperatures in negative level bins and decreased - in positive bins are caused by upwelling and downwelling, respectively. The diagrams constructed for the rest of years confirm the cold content deficit of the Black Sea CIL by the end of 1993 - 2002 period.
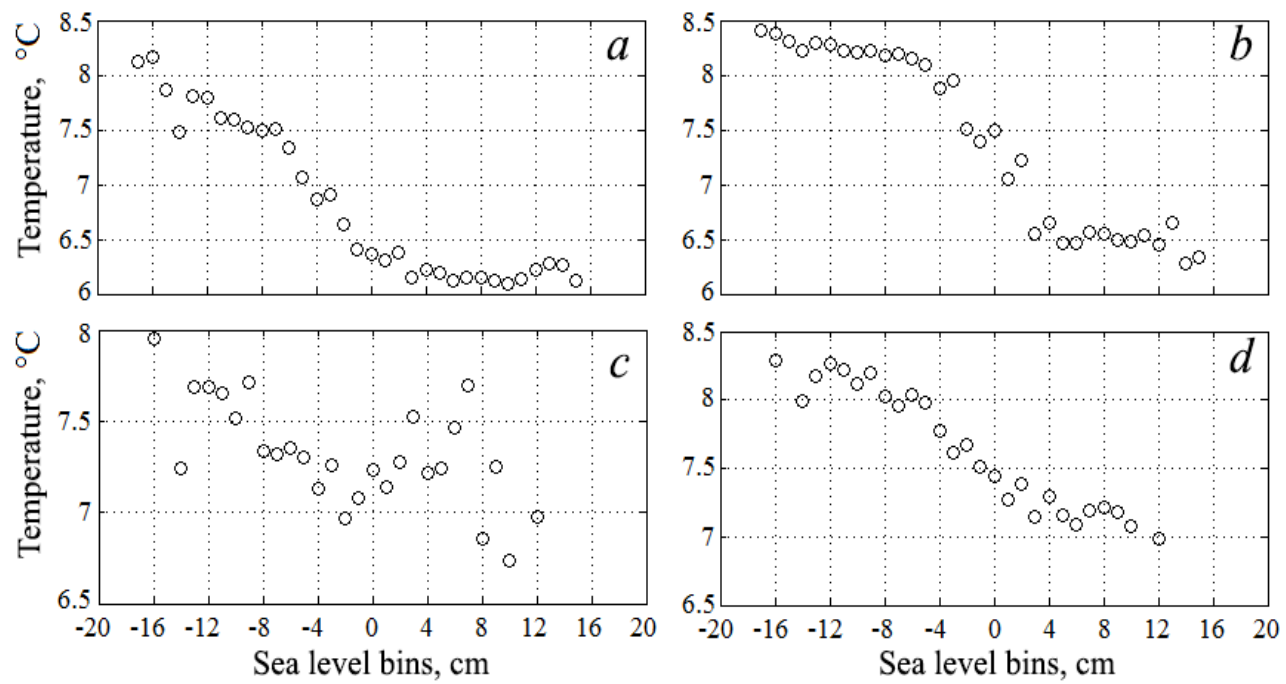

Fig. 3. Diagrams of monthly average temperature values for each sea level bin at $63 \mathrm{~m}$ horizon $(a, c)$ and $88 \mathrm{~m}$ horizon $(b, d)$ for May $1993(a, b)$ and May $1995(c, d)$

The values of dispersions (Fig. 2, $c, d$ ) in several bins, both by temperature and salinity, are sufficiently high. The cause of this fact is a long time interval of measurement data acquisition and insufficient statistical provision.

\section{Profiles of undisturbed salinity and temperature}

From the entire set of obtained for level bins monthly average salinity and temperature profiles we will select the profiles of zero bin (so-called undisturbed salinity and temperature profiles). This bin lies in "- $1,0,1$ " range of altimetry dynamic level of the Black Sea. Zero bin profiles allow us to determine the shifts of isohaline and isopycnic surfaces caused by adiabatic reversible processes.

We consider features of monthly average vertical profiles of undisturbed salinity in $0-200$ m layer (Fig. 4, a, c). At first, we should notice that in 1993 the salinity profiles were obtained for each month. At the same time, 3-months measurement acquisition interval allowed to construct the vertical profiles of undisturbed salinity only for March - August, 1996 period. For March and April, as well as for June and July the profiles of undisturbed salinity are the same. Repetition of the same salinity (temperature) profiles for neighboring months in 1996 and 1997 is caused by small number of measurements. 

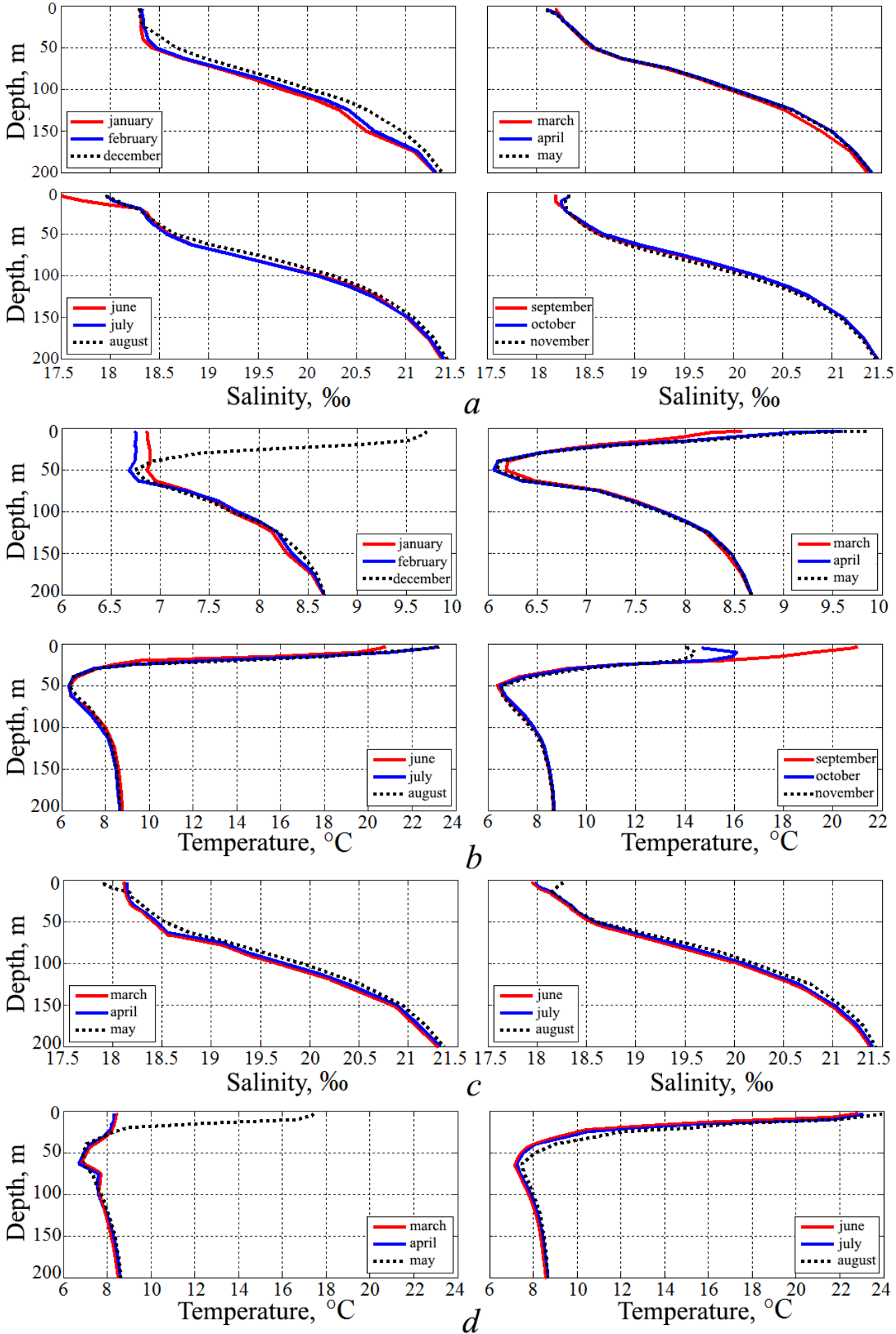

Fig. 4. Monthly average vertical profiles of salinity $(a, c)$ and temperature $(b, d)$ of zero level bin in 0 - 200 m layer: $a, b-1993 ; c, d-1996$ 
Qualitative and quantitative data on vertical profiles of undisturbed salinity and temperature are represented below. A characteristic feature of salinity vertical structure is the existence of two haloclines - seasonal and permanent. Seasonal halocline is observed in April - September in $0-25 \mathrm{~m}$ layer (Fig. 4, a) and in $0-$ 20 m layer (Fig. 4, c). Upper quasihomogeneous sea layer in 1993 is manifested well from November to March. Its maximum depth $(\sim 38 \mathrm{~m})$ is observed in January. The depth of permanent (main) halocline is $50-150 \mathrm{~m}$.

Undisturbed temperature profiles for 1993 and 1996 (Fig. 4, b, d) demonstrate main features of the Black Sea vertical thermal structure. In January and February 1993 (cold winter) quasihomogeneous layer of $\sim 50 \mathrm{~m}$ maximum depth distinguishes clearly. Temperature inversions in October and November are explained by autumn cooling of surface waters. In March and April surface water warms up, in June - September in $0-40 \mathrm{~m}$ layer a pronounced thermocline is observed. Cold intermediate layer is clearly seen in June - October, 1993 at the depths from 25 - $35 \mathrm{~m}$ to $100 \mathrm{~m}$. Temperature in June - August, 1996 (normal winter) in subsurface minimum layer is about $1{ }^{\circ} \mathrm{C}$ higher than in the same months in 1993.
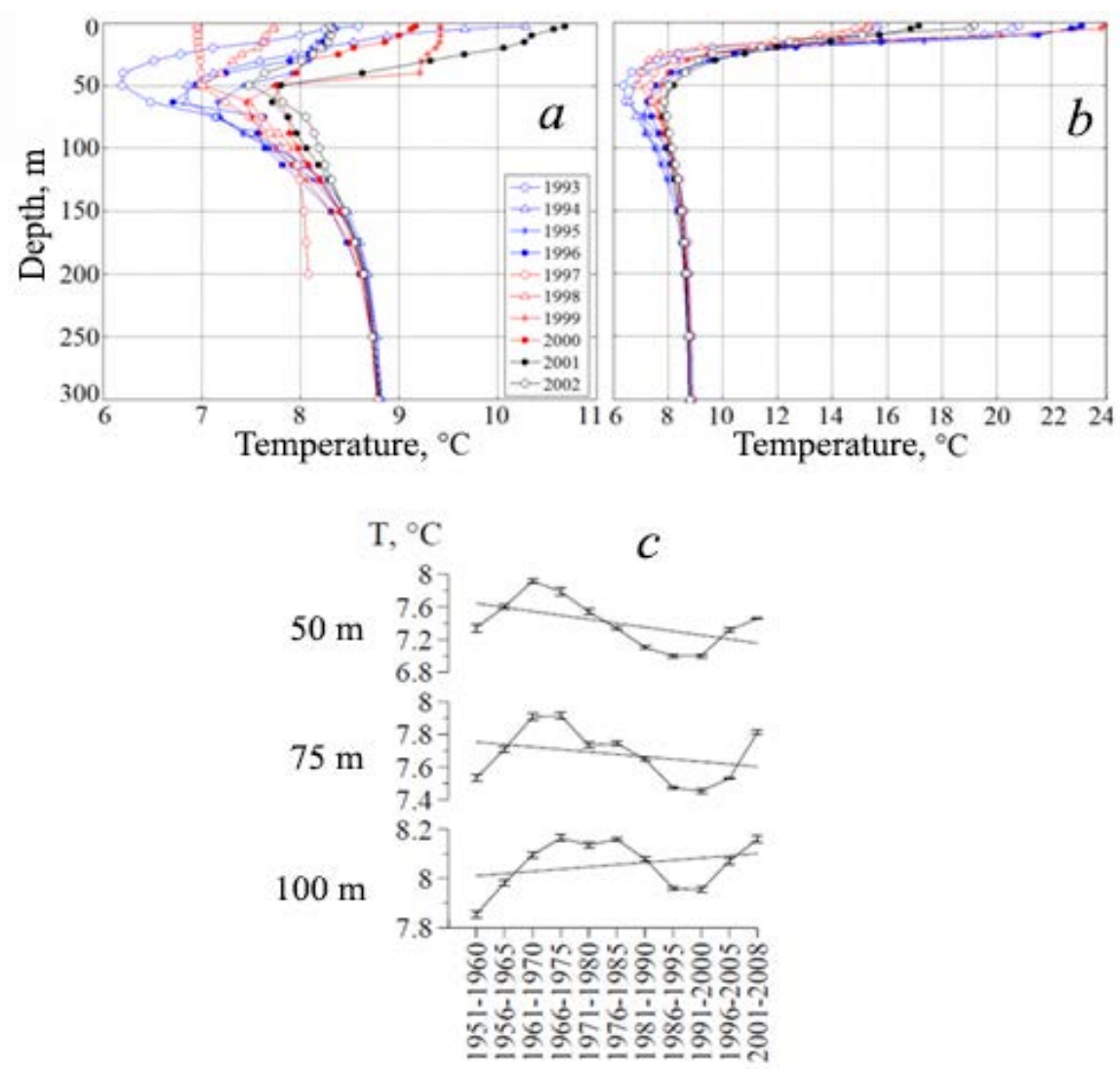

Fig. 5. Temperature profiles of zero level bin in 0 - 300 m layer: $a$ - March $1993-2002 ; b$ - June 1993 - 2002; $c$ - interdecadal variability of temperature averaged at temperature horizons [17] 
The interannual variability of undisturbed temperature profiles indicates that the greatest cold content is observed in 1993 (Fig. 5). In other years it decreases and it agrees with interdecadal temperature variability [15 - 17]. It manifests itself especially clear at 50, 75 and 100 m horizons at 1991 - 2000, 1996 - 2005, $2001-$ 2008 interdecadal periods of time (Fig. 5, c). The highest CIL temperature is observed in July, 2002 profile.

We should notice that the station measurements in most cases had been performed down to $500-600 \mathrm{~m}$ depths and in some cases - down to $200 \mathrm{~m}$ (Fig 5, a). In addition, due to the insufficient number of measurements in some months the monthly profiles are dominated by the station data of one of the neighboring months, not by the data of average month, which is related to this profile (e. g. monthly average temperature and salinity profile for March, 1997 is calculated only according to the data of stations for April, 1997).
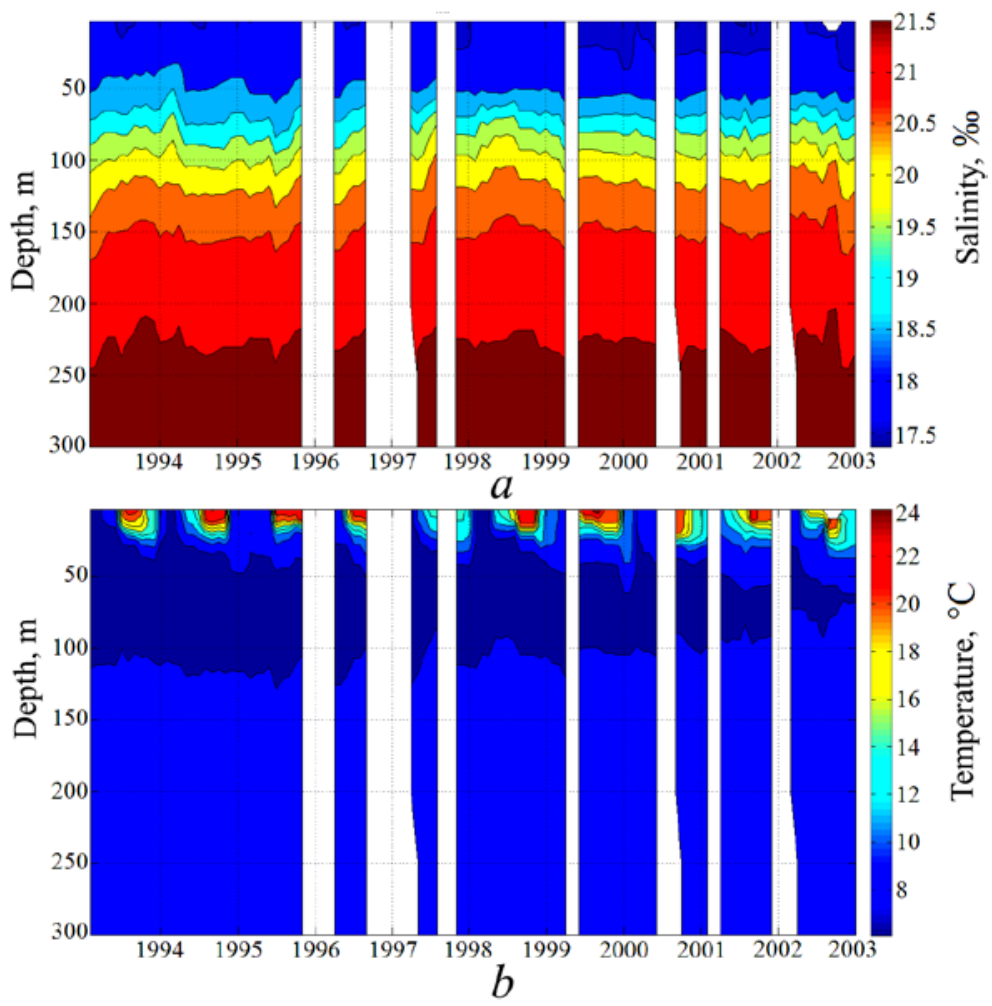

Fig. 6. Diagrams of seasonal and interannual variability of monthly average salinity $(a)$ and temperature (b) profiles of zero level bin in 0 - 300 m layer for $1993-2002$ period

Monthly average profiles of undisturbed temperature and salinity, obtained in accordance with the described technique, qualitatively depict seasonal and interannual variability of the Black Sea thermohaline parameters, which is typical for 1993 - 2002 period (Fig. $6 a, b$ ). However, there are some months at the diagrams for which we are unable to restore the profiles of undisturbed temperature and salinity by means of proposed technique. 


\section{Correction of undisturbed temperature and salinity monthly average profiles}

Monthly average profiles of salinity and temperature for some months, obtained by the proposed technique, have a disadvantage, which consists in the fact that the key role (in the closed form of these profiles) may be played by the station measurements performed at the beginning of in the end of acquisition interval. In this case monthly average temperature (salinity) may be decreased or increased, respectively. The considered problem is especially relevant for months, which are poorly provisioned with measurements. The provision level of average (for three months) temperature and salinity profile of zero bin was determined by the amount of hydrological stations. 1996 and 1997 were statistically poorly provisioned. In these years the threshold quantity of stations was not less than three. In other years the provisioning of zero bin profiles was a bit higher (Fig. 7). Temperature and salinity profile of zero bin reached a peak of statistical provision in 1993 (minimum amount of stations - 6, maximum - 47).
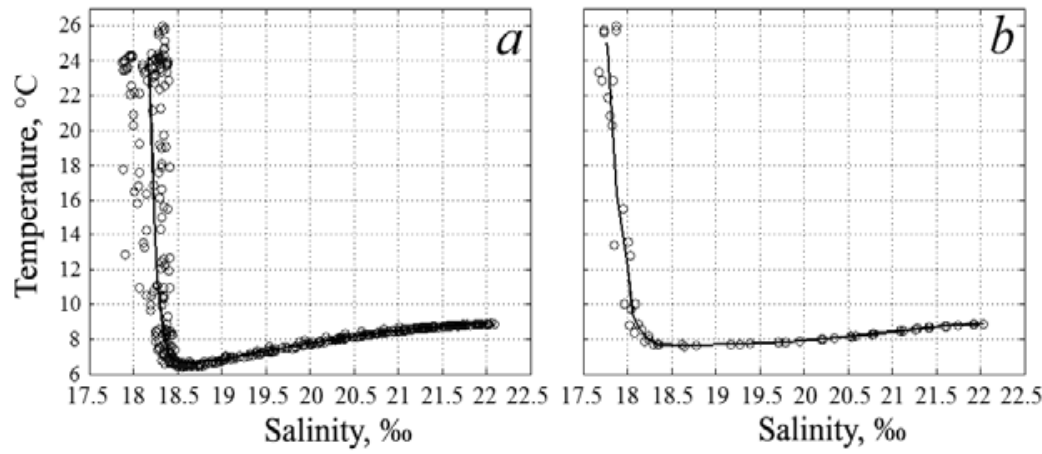

Fig. 7. T, S-curves of zero level bin for August of: $a-1994 ; b-1999$. Temperature and salinity measured at the stations are marked by bubbles

Profiles, provisioned by one or two measurement stations, were verified for the time of execution of these stations. The following acquisition interval was chosen: the second part of the first month, average month and the first part of the third month. Station measurement data were considered if the stations got into "truncated" acquisition interval. If the station measurements didn't get into the selected interval or there were no measurements at all, the zero bin "- $1,0,1$ " cm was extended to "-2, 0,2 " $\mathrm{cm}$. In that case when new stations occurred due to extended level bin, the recalculation of monthly average temperature and salinity was performed. By means of zero bin boundary extension there were obtained (in addition) the profiles for the following months: March, October, November, December, 1997; December 1999; January, October, 2000; March, August, September 2002. If the boundary extension of a zero bin didn't lead to the desired result, the monthly average profiles for the given month were restored by means of linear interpolation between the known profiles. Thus, the continuous array of monthly average profiles of undisturbed temperature and salinity of the whole 1993 - 2002 period (120 months) for 0 - 500 depths was developed (Fig. 8). 

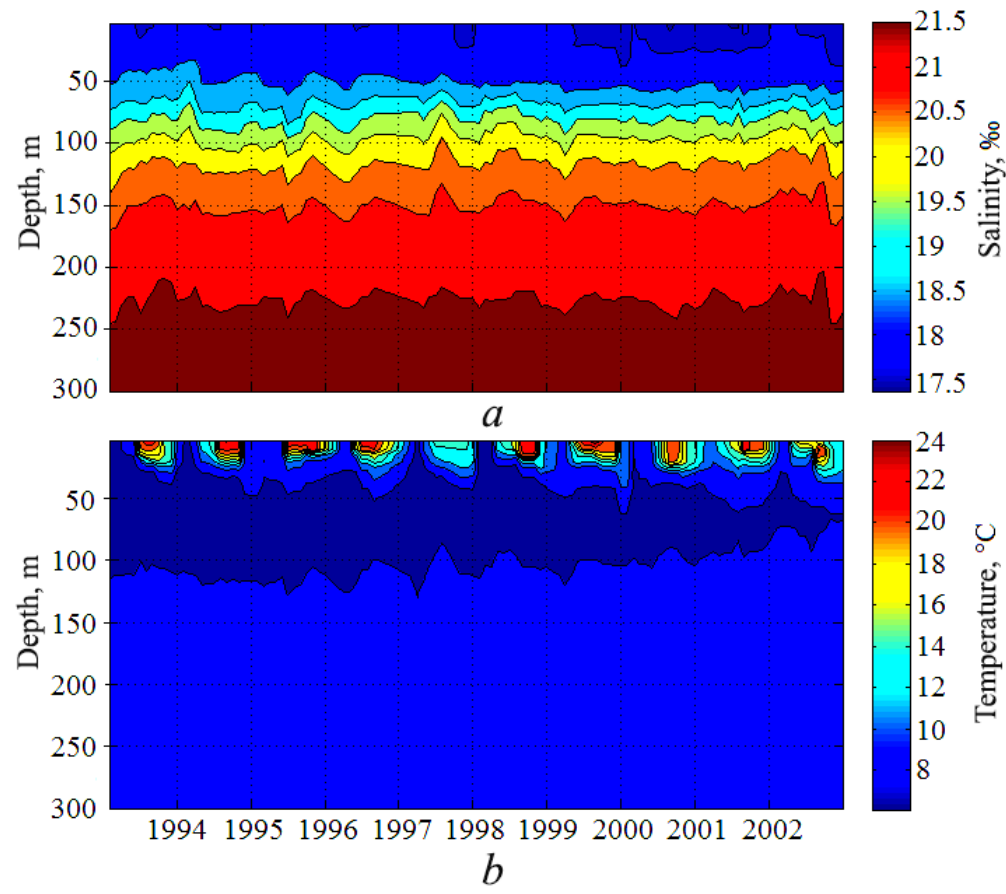

Fig. 8. Diagrams of seasonal and interannual variability of monthly average salinity $(a)$ and temperature $(b)$ profiles of a zero level bin considering the interpolation in 0 - $300 \mathrm{~m}$ layer for 1993 2002 period

Fig. 8, $a$ indicates the desalination of waters in the upper 50 m layer by the end of the considering period. In the interannual variability the cold content decrease of CIL is observed more obvious (Fig. 8, b). The obtained temperature profiles also represent its seasonal variability. Particularly, the formation of seasonal thermocline in $\sim 8-25$ m layer is clearly observed. We should point out one more time that using the given technique there is no chance of layer thickness change because of oscillations of isohaline and isothermal surfaces.

\section{T, S-curves analysis of "zero" and "non-zero" altimetry level bins}

According to the data of temperature and salinity monthly average profiles for each month of the entire period the $T$, $S$-curves were constructed (for "zero" bin and for all other level bins). For the analysis there were generally used the months wellprovisioned with measurement data. The following $T, S$-characteristics correspond to 100 m depth: $S=19.86 \%, T=7.79^{\circ} \mathrm{C}$ (Fig. 9, $a$ ); $S=19.98 \%, T=7.76^{\circ} \mathrm{C}$ (Fig. 9, b); $S=20.27 \%, T=7.93^{\circ} \mathrm{C}$ (Fig. 9, $c$ ); $S=20.11 \%$, $T=7.75^{\circ} \mathrm{C}$ (Fig. 9, $d$ ). The large spread of measured temperature and salinity values in the Black Sea upper water mass in relation to $T, S$-curves of "zero" bin is a consequence of atmosphere (precipitation, evaporation, wind, heat flows) and river streamflow effect. The spread become smaller with the depth increase. Profiles of measured at the stations temperature and salinity, regardless of their spatial location and execution time, converge from $\sim 100 \mathrm{~m}$ depth. The Black Sea water mass, which occupies the layer 
from $50-100 \mathrm{~m}$ to $1100-1200 \mathrm{~m}$, is usually called the Black Sea intermediate water mass according to classification of the works $[18,19]$. Converge of $T, S$-curves, constructed in accordance with the measurement data of different stations, confirms that these curves belong to the same water mass.
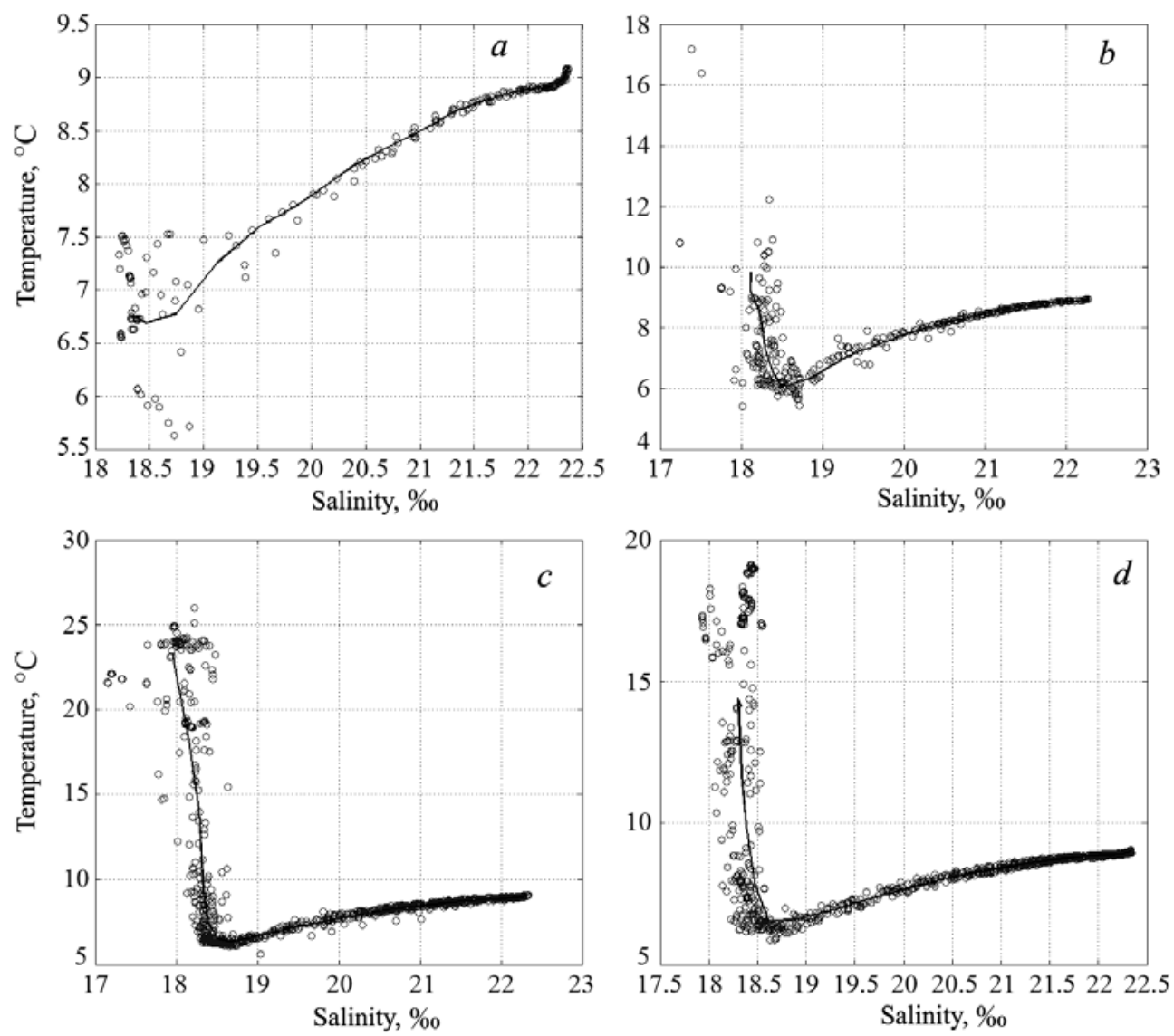

Fig. 9. $T$, S-curves of zero level bin for 1993: $a$ - February; $b$ - May; $c$ - August; $d$ - November

Seasonal variability features of $T$, S-curves of zero level bin through the example of 1993 consist in the following facts. The salinity minimum in the upper layer falls on the spring-summer period. It is conditioned by the effect of the waters desalinated due to the spring flooding of rivers (Fig. 9, $b, c$ ). In autumn-winter period a gradual salinity increase is observed (Fig. $9 a, d$ ). Cold intermediate layer is clearly manifested at $T, S$-curves in all seasons and is characterized by relatively low temperatures. February $T, S$-curve reflects winter convective water mixing under the extreme effect of atmosphere winter conditions on the marine environment. Spring and summer curves reflect gradual temperature rise in the surficial sea layer and "blocking" of renewed CIL (Fig. 8).

The desalination of upper sea layer and CIL temperature increase in 1999 in comparison with 1994 (Fig. 7 and 8) are pronounced at $T$, S-curves of zero level bin in summer in interannual variability. The salinity in $0-30 \mathrm{~m}$ layer has 
decreased, on average, by $0.25 \%$. The temperature minimum falls on $63 \mathrm{~m}$ horizon, in 1994 it was $6.59^{\circ} \mathrm{C}$, in $1999-7.64^{\circ} \mathrm{C}$.

The features for a zero bin (described above) are also valid for other bins. The profiles of measured at stations temperature and salinity, included in other bin, also converge from about $100 \mathrm{~m}$ and deeper (Fig. 10, $a, b$ ), which indicates the predomination of adiabatic displacements of isothermal and isohaline surfaces at these depths. $T, S$-indexes of curves at these depths, which belong to "non-zero" bins of altimetry level, characterize the same intermediate water mass of the Black Sea. This feature is traced during the whole 1993 - 2002 period.
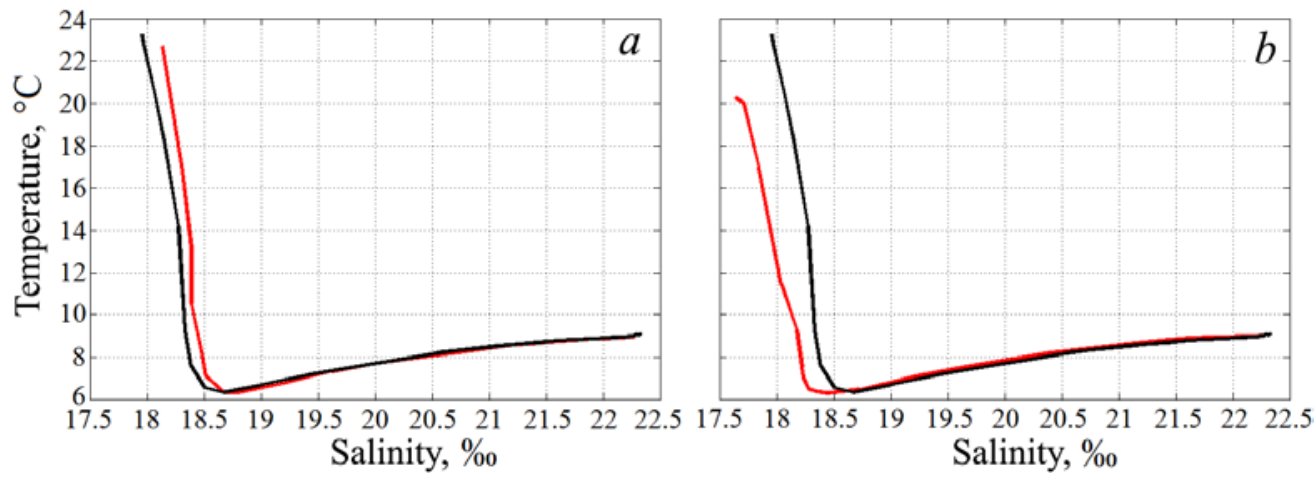

Fig. 10. $T$, $S$-curves of selected level bins for August, 1993: “«-7, -6” cm (red curve) - a; “6, 7” cm (red curve) - $b$; “-1.0, 1 ” cm (black curve) - "zero” level bin

Seasonal and interannual $T$, S-curves variability analysis of "zero" and other level bins in 63 - 100 layer during 1993 - 2002 period confirmed the abovementioned CIL temperature increase by the end of the considered period. We should notice that the temperature at $50 \mathrm{~m}$ horizon was $8{ }^{\circ} \mathrm{C}$ higher in summer months of 2001 and 2002, and at $100 \mathrm{~m}$ depth - in all months of the considered period, which indicates the CIL thickness decrease in these years (Fig. 8).

Analyzing $T, S$-curves under various bins of level surface displacement in 0 $100 \mathrm{~m}$ layer it should be noticed an interesting law. $T$, $S$-curves, which correspond to negative level bins, displace to right from "unperturbed". This effect is especially pronounced in $0-65 \mathrm{~m}$ layer (Fig. 10, $a$ ). Let us remind that negative bins match up with the areas of cyclonic gyres where saltier waters rise to the surface. Therefore, “-7, -6" cm bins in Fig. 10, $a$ corresponds mostly to the central part of the Black Sea. CIL area lies within $18.49-20.28 \%$ salinity values. This conclusion qualitatively agrees with the data of the work [20], according to which CIL area was situated in the central part of the sea and in July, 1992 (cold winter) was characterized by $18.35-20.24 \%$ salinity values.

At the same time, $T$, $S$-curves corresponding to "6, 7" cm positive level bins in Fig. 10, $b$ displace to the left from "unperturbed" $T, S$-curve. This effect is especially pronounced in $0-65 \mathrm{~m}$ layer.

The above-mentioned tendency of $T$, $S$-curve displacement, depending on the level bin, is typical for winter-spring season, and it becomes the opposite in summer-autumn season. However, within the CIL such tendency becomes more complex and, apparently, depends on its intensity. In this regard, it is necessary to PHYSICAL OCEANOGRAPHY NO. 2 (2015) 
consider the description of temperature variability (in winter and summer seasons) dependence on level bin with constant salinity. Now we should consider 1993, 1994, 1998 years, characterized by cold winters, and 1995 year when, according to our data, there was no winter replenishment (Fig. 8). Constant salinity amounts $18.5 \%$, which characterizes the subsurface water mass - cold intermediate layer. During the transition of level bins from negative to positive the temperature increased in February 1993, 1994 and 1998, decreased in August 1993 and 1994 but increased in August 1998. In February and August 1995 in the conditions of warm winter temperature decreased with the level bin raise. Thus, the tendency of $T$, S-curve displacement, taking into account the level bins near CIL, depends on its intensity and salinity value in its core.

It may be assumed that the revealed effect is caused by desalination of surface sea waters in the areas of anticyclonic formations. However, similar results may be caused by different vertical diffusion rate of heat and salt.

\section{Conclusions}

An original technique of joint analysis of irregular by space and time temperature and salinity hydrological measurement data and satellite altimetry observations is proposed. It is based on the construction of empirical relationships between temperature and salinity monthly average values in the area bounded by $500 \mathrm{~m}$ isobath and different altimetry level bins of the Black Sea. The research is performed for 1993 - 2002 period when the number of hydrological ship observations was rather limited.

From the set of obtained monthly average temperature and salinity profiles (with regard to the adiabatic approximation), the ones of "-1, $0,1 " \mathrm{~cm}$ zero level bin, considered as unperturbed, were selected, corrected and analyzed. The diagrams of seasonal and interannual unperturbed salinity profiles in $0-300 \mathrm{~m}$ layer indicate the desalination of waters in upper $50 \mathrm{~m}$ layer by the end of 1993 2002 period. In the interannual variability of monthly average profiles of unperturbed the decrease of CIL thickness is observed.

The analysis of $T, S$-curves of zero and non-zero level bins allowed us to determine that profiles of measured at stations temperature and salinity, in spite of their spatial location and execution time, converge in $100-1200 \mathrm{~m}$ layer. This fact characterizes the Black Sea water mass and indicates the predominant role of adiabatic processes at these depths.

At the same time the performed analysis shows that there is a certain regularity of $T, S$-curves location depending on the level bins. This regularity has a seasonal variability and becomes more complex in the core of cold intermediate layer.

Acknowledgements. The authors express deep gratitude to V.N. Belokopytov for providing temperature and salinity measurement arrays for 1979 - 2012 period.

The research was carried out within the framework of scientific project No.1445-01548, Russian Fund for Basic Research.

\section{REFERENCES}

1. AVISO - Archivage Validation Interprétation des données des Satellites Océanographiques, http://www.aviso.oceanobs.com/. 
2. Kubryakov, A.A., Stanichny, S.V., 2013, "Estimating the quality of the retrieval of the surface geostrophic circulation of the Black Sea by satellite altimetry data based on validation with drifting buoy measurements”, Izvestiya. Atmos. Ocean. Phys., vol. 49, no. 9, pp. 930938.

3. Le Traon, P.Y., Dibarboure, G. \& Ducet, N., 2002, "Use of a high-resolution model to analyze the mapping capabilities of multiple-altimeter missions”, J. Atmos. Ocean. Technol., no. 18, pp. 1277-1288.

4. Pascual, A., Faugère, Y. \& Larnicol, G. [et al.], 2006, "Improved description of the ocean mesoscale variability by combining four satellite altimeters”, Geophys. Res. Lett., no. 33, L02611.

5. Korotayev, G.K., Knysh, V.V. \& Mizyuk, A.I., 2010, “Avtomodel'noe formirovanie psevdopoley nablyudeniy plotnosti (solenosti, temperatury) Chernogo morya dlya resheniya zadachi re-analiza gidrofizicheskikh poley (model'nye chislennye eksperimenty) [Automodel formation of the Black Sea density (salinity and temperature) observation pseudo-fields to solve the problem of the re-analysis of the hydrophysical fields (model numerical experiments)]", Ekologicheskaya bezopasnost' pribrezhnoy i shel'fovoy zon i kompleksnoe ispol'zovanie resursov shel'fa, vol. 22, pp. 7-21 (in Russian).

6. Mizyuk, A.I., Knysh, V.V. \& Korotayev, G.K., 2011, "Metodika vosstanovleniya gidrofizicheskikh poley Chernogo morya v period 2007 - 2008 gg. na osnove assimilyatsii $v$ modeli dannykh izmereniy buev-profilemerov [Renovation technique of the Black Sea hydrophysical fields in 2007 - 2008 period based on the assimilation in the model of data measurement of profiling floats]", Ekologicheskaya bezopasnost' pribrezhnoy i shel'fovoy zon i kompleksnoe ispol'zovanie resursov shel'fa, vol. 24, pp. 38-55 (in Russian).

7. Belokopytov, V.N., Bagaev, A.V., 2012, "Statisticheskiy analiz termokhalinnykh poley Chernogo morya po dannym buev-profilemerov ARGO [Statistical analysis of the Black Sea thermohaline fields under the data of ARGO profiling floats]", Ekologicheskaya bezopasnost' pribrezhnoy i shel'fovoy zon i kompleksnoe ispol'zovanie resursov shel'fa, vol. 26, pp. 128142 (in Russian).

8. Bagaev, A.V., Korotaev, G.K. \& Demyshev, S.G. [et al.], 2011, "Sopostavlenie rezul'tatov modeliro-vaniya termokhalinnykh poley Chernogo morya s dannymi buev-profilemerov $A R G O$ [Association of the results of the Black Sea thermohaline fields with the data of ARGO profiling floats]”, Ekologicheskaya bezopasnost' pribrezhnoy i shel'fovoy zon i kompleksnoe ispol'zovanie resursov shel'fa, vol. 24, pp. 78-90 (in Russian).

9. Knysh, V.V., Kubryakov, A.I. \& Inyushina, N.V. [et al.], 2008, "Vosstanovlenie klimaticheskoy sezonnoy tsirkulyatsii Chernogo morya na osnove modeli $v$ r-koordinatakh $s$ ispol'zovaniem assimilyatsii dannykh o temperature $i$ solenosti [The Black Sea seasonal climatic circulation renewal based on the model in $\sigma$-coordinates applying temperature and salinity data assimilation]", Ekologicheskaya bezopasnost' pribrezhnoy i shel'fovoy zon $i$ kompleksnoe ispol'zovanie resursov shel'fa, vol. 16, pp. 243-265 (in Russian).

10. Titov, V.B., 2000, "Formirovanie zimney gidrologicheskoy struktury Chernogo morya $v$ zavisimosti ot surovosti zim [Dependence of the Formation of the Winter Hydrological Structure in the Black Sea on the Severity of Winter Conditions]”, Okeanologiya, vol. 40, no. 6, pp. 826-832 (in Russian).

11. Titov, V.B., Savin, M.T., 2000, "Ob otsenke temperaturnogo rezhima atmosfery, formiruyushchego gidrologicheskuyu strukturu Chernogo moray [Estimation of atmospheric temperature regime forming the hydrological structure of the Black Sea]", Meteorologiya i gidrologiya, no. 10, pp. 78-84 (in Russian).

12. Titov, V.B., 2003, "Vliyanie mnogoletney izmenchivosti klimaticheskikh usloviy na gidrologicheskuyu strukturu i mezhgodovoe obnovlenie kholodnogo promezhutochnogo sloya $v$ Chernom more [Effect of multiannual variability of climatic conditions on the hydrological structure and interannual renewal of the cold intermediate layer in the Black Sea]", Okeanologiya, vol. 43, no. 2, pp. 176-184 (in Russian). 
13. Staneva, J.V., Stanev, E.V., 2002, "Water mass formation in the Black Sea during 19911995”, J. Mar. Syst., no. 32, pp. 199-218.

14. Stanev, E.V., Bowman, M.J. \& Peneva, E.L. [et al.], 2003, “Control of Black Sea intermediate water mass formation by dynamics and topography: Comparison of numerical simulations, surveys and satellite data”, J. Mar. Res., no. 61, pp. 59-99.

15. Oguz, T., Dippner, J.W. \& Kaymaz, Z., 2006, "Climatic regulation of the Black Sea hydrometeorological and ecological properties at interannual-to-decadal time scales”, J. Mar. Syst., vol. 60, iss. 3-4, pp. 235-254.

16. Shokurova, I.G., 2010, “Dolgovremennaya izmenchivost' gidrologicheskikh poley $i$ geostroficheskoy tsirkulyatsii $v$ Chernom more [Long-period variability of hydrologic fields and geostrophic circulation in the Black Sea]", PhD Thesis, Sevastopol, MGI NAN Ukrainy, 176 p. (in Russian).

17. Polonsky, A.B., Shokurova, I.G. \& Belokopytov, V.N., 2013, “Desyatiletnyaya izmenchivost' temperatury $i$ solenosti $v$ Chernom more [Decadal variability of temperature and salinity in the Black Sea]”, Morskoy gidrofizicheskiy zhurnal, vol. 6, pp. 27-40 (in Russian).

18. Leonov, A.K., 1960, "Regional'naya okeanografiya. Chast' 1. Beringovo, Okhotskoe, Yaponskoe, Kaspiyskoe i Chernoe morya”, Leningrad, Gidrometeoizdat, 765 p. (in Russian).

19. Ivanov, V.A., Belokopytov, V.N., 2011, "Okeanografiya Chernogo morya”, Sevastopol, ECOSI-Gidrofizika, 209 p. (in Russian).

20. Polonskii, A.B., Popov, Yu.I., 2011, "Usloviya formirovaniya vod kholodnogo promezhutochnogo sloya Chernogo morey [Formation conditions of the Black Sea intermediate cold layer waters]", Seriya: Sovremennye problemy okeanologii, ECOSIGidrofisika, iss. 8, 54 p. (in Russian). 